\title{
CARBON DIOXIDE AND METHANE EMISSIONS BY URBAN TURFGRASSES UNDER DIFFERENT NITROGEN RATES: A COMPARISON BETWEEN TALL FESCUE (FESTUCA ARUNDINACEA SCHREB.) AND HYBRID BERMUDAGRASS (CYNODON DACTYLON [L.] PERS. VAR. DACTYLON X CYNODON TRANSVAALENSIS BURTT-DAVY)
}

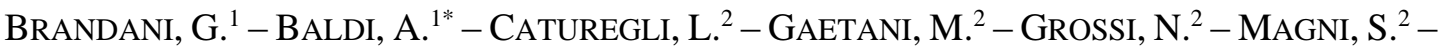 \\ PARDINI, A. ${ }^{1}$ - VOLTERRANI, M. ${ }^{2}$ - ORLANDINI, S. ${ }^{1}-$ VERDI, L. ${ }^{1}$ \\ ${ }^{1}$ Department of Agriculture, Food, Environment and Forestry, University of Florence \\ Piazzale delle Cascine, 18, 50144 Firenze (FI), Italy \\ (phone: +39-055-275-5700) \\ ${ }^{2}$ Department of Agriculture, Food and Environment, University of Pisa \\ Via del Borghetto, 80, 56124 Pisa (PI), Italy \\ (phone: +39-050-221-6090) \\ "Corresponding author \\ e-mail: ada.baldi@unifi.it; phone: +39-055-275-5936 \\ (Received $15^{\text {th }}$ Feb 2020; accepted 25 $5^{\text {th }}$ May 2020)
}

\begin{abstract}
Turfgrass is a major vegetation type in urban and peri-urban areas. Being high maintenance ecosystems, turfs can contribute substantially to urban climate change. The object of this study was to evaluate the contribution to GHG emissions by urban turfgrasses in Mediterranean conditions (Tuscany, central Italy). $\mathrm{CO}_{2}$ and $\mathrm{CH}_{4}$ emission fluxes from a mature stand of tall fescue and bermudagrass were evaluated, by static chambers method, for the assessment of $\mathrm{C}$ emission under different nitrogen fertilization rates $\left(0-50-150 \mathrm{~kg} \mathrm{~N} \mathrm{ha}^{-1}\right)$. Both species showed a correlation between $\mathrm{N}$ fertilization rate and $\mathrm{CO}_{2}$ emissions, whilst, no correlation was observed for $\mathrm{CH}_{4}$. In the case of tall fescue, cumulative $\mathrm{CO}_{2}$ emissions were significantly higher with $150 \mathrm{~kg} \mathrm{~N} \mathrm{ha}^{-1}$ and no differences were observed between 0 and $50 \mathrm{~kg} \mathrm{~N} \mathrm{ha}^{-1}$. As for bermudagrass differences were found between control and other treatments but no differences were observed on cumulative $\mathrm{CO}_{2}$ emissions between 50 and $150 \mathrm{~kg} \mathrm{~N}$ ha $^{-1}$. In both species, $\mathrm{N}$ fertilization did not affect $\mathrm{CH}_{4}$ emissions. Results indicate that both $\mathrm{N}$ rate and turfgrass species influence $\mathrm{C}$ emissions, for this reason they should be considered in the management of green areas in the climatic transition zone.
\end{abstract}

Keywords: greenhouse gasses, static chambers, fertilization, green areas, turf management

\section{Introduction}

Greenhouse gas emissions are now higher than ever, attracting broad interest because of their potential implications with climate change (Lal et al., 1995; Verdi et al., 2019). Given the high amount released into the atmosphere, carbon dioxide $\left(\mathrm{CO}_{2}\right)$ can be considered the major contributor to the greenhouse effect (Forster et al., 2007). Since the mid-nineteenth century, almost $35 \%$ of $\mathrm{CO}_{2}$ released by human activities has been associated with changes in land use (Houghton et al., 2001). The contribution of land use to global warming is difficult to be determined since greenhouse gases (GHGs) derive from diverse sources and complex systems (Foley et al., 2005).

Urbanization is one of the main causes of the change in land use (Patra et al., 2018) and urban and peri-urban areas are expected to sprawl rapidly in the next future (d'Amour et al., 2017; Ritchie and Roser, 2020). As the urban citizen density is destined to growth in 
the coming decades (United Nations, 2014), urban land use and land cover has gained more attention because of the impact that anthropic activities have on ecosystems. Urbanization implies an increase in turf's environmental impacts due to the replacement of natural and agricultural lands with this type of green cover (Alig and Kline, 2004; Kaye et al., 2004; Caturegli et al., 2014; Magni et al., 2014). Thanks to its functional, environmental, recreational, social and aesthetic roles, nowadays turfgrass is the most important vegetation type in urban and peri-urban environment (Qian and Follet, 2012) covering more than 16 million ha in the United States of America (Milesi et al., 2005) and up to 70-75\% of urban green spaces worldwide (Ignatieva et al., 2015).

Turfgrasses establishment and maintenance at high quality levels contribute substantially to carbon emissions in atmosphere. Van Delden et al. (2016) found that turfgrass establishment increases the global warming potential by another $30 \mathrm{~kg} \mathrm{CO}_{2}$-e per ha in comparison with the native eucalypt forest in Brisbane (Australia), while Kong et al. (2014) state that turf maintenance contributes to carbon emissions at 0.17 to $0.63 \mathrm{~kg} \mathrm{CO}_{2}$ e per month per year in Hong Kong. Furthermore, turfgrasses have the capacity to store carbon (C) (Jo and McPherson, 1995; Nowak and Crane, 2002; Jo, 2002). Due to the high variability observed on turfgrass capacity to store $\mathrm{C}$, annual $\mathrm{C}$ storage rate varies among 0.9 tons $\mathrm{C} \mathrm{ha}^{-1} \mathrm{y}^{-1}$ to 5.4 tons $\mathrm{C} \mathrm{ha}^{-1} \mathrm{y}^{-1}$ (Selhorst and Lal, 2013). Furthermore, Selhorst and Lal (2013) found that the most managed is the lawn, the highest is its C storage rate depending on species, turf age, and management. On the contrary, turfgrasses may represent a detrimental factor due to their potential to affect the carbon cycle being $\mathrm{CO}_{2}$ and methane $\left(\mathrm{CH}_{4}\right)$ sources, increasing carbon emissions and carbon concentration in the atmosphere (Groffman and Pouyat, 2009). In these regards, within their experiments in Moscow city, Shchepeleva et al. (2007) estimated C balance of turfgrass comparing the annual $\mathrm{C}$ uptake in biomass with the $\mathrm{CO}_{2}$ emission from soils and the results showed that $\mathrm{C}$ uptake did not compensate $\mathrm{C}$ emissions. Depending on $\mathrm{N}$ fertilization rate, Hamido et al. (2016) found a turfgrass emission range going from 292 to $394 \mathrm{~kg} \mathrm{CO}_{2} \mathrm{ha}^{-1} \mathrm{~d}^{-1}$. Allaire et al. (2008) state that turfgrass $\mathrm{CO}_{2}$ emissions are neglected because of an underestimation of the contribution that urban land area could give since they are considered generally too small. On the contrary, according to Robbins and Birkenholtz (2003), turfgrasses occupy a substantial part of urban surfaces with an essential contribution to $\mathrm{CO}_{2}$ emission. Groffman and Pouyat (2009) found that $\mathrm{CH}_{4}$ uptake is almost completely absent in lawns, Selhorst and $\mathrm{Lal}$ (2013) found that $\mathrm{CH}_{4}$ emissions depend on the decomposition of biomass. $\mathrm{CO}_{2}$ and $\mathrm{CH}_{4}$ emission rates from soil depend on many factors and soil characteristics such as microbial activity, root and heterotrophic respiration, soil texture, temperature, moisture, and pH (Ludwig et al., 2001; Rastogi et al., 2002; Groffman and Pouyat, 2009). Zhang et al. (2013) state that also the management is crucial because of the impact that it can bring to the soil-atmosphere gas exchange system. Urban and peri-urban areas are highly managed ecosystems (Zhang et al., 2013) requiring even daily irrigation, frequent mowing and fertilization treatments. However, they are not analyzed as deeply as forest and agricultural soils, thus quantifying their carbon emissions is a complex matter (Jo and McPherson, 1995; Pouyat et al., 2002, 2006; Townsend-Small and Czimczik, 2010).

The object of this study was to evaluate the effect of nitrogen fertilization on the contribution to GHG emissions by urban turfgrasses. For this purpose, $\mathrm{CO}_{2}$ and $\mathrm{CH}_{4}$ emission fluxes from a mature stand of tall fescue (Festuca arundinacea Schreb.) and hybrid bermudagrass (Cynodon dactylon [L.] Pers. var. dactylon x Cynodon transvaalensis Burtt-Davy), two of the most commonly used turfgrass species, were evaluated for the assessment of $\mathrm{C}$ total amount emission at different nitrogen fertilization rates. 


\section{Materials and methods}

The experiment was carried out from May to September 2018 at the Centre for Research on Turfgrass for Environment and Sports (CeRTES) (Fig. 1), University of Pisa, located at San Piero a Grado, Pisa $\left(43^{\circ} 40^{\prime} \mathrm{N}, 10^{\circ} 19^{\prime} \mathrm{E}, 6 \mathrm{~m}\right.$ a.s.l.), Italy, on mature turfgrass stands of the cool-season $\left(\mathrm{C}_{3}\right)$ 'Grande' tall fescue (Festuca arundinacea Schreb.) and the warm-season $\left(\mathrm{C}_{4}\right)$ 'Patriot' hybrid bermudagrass (Cynodon dactylon [L.] Pers. var. dactylon x Cynodon transvaalensis Burtt-Davy) (Caturegli et al., 2015).

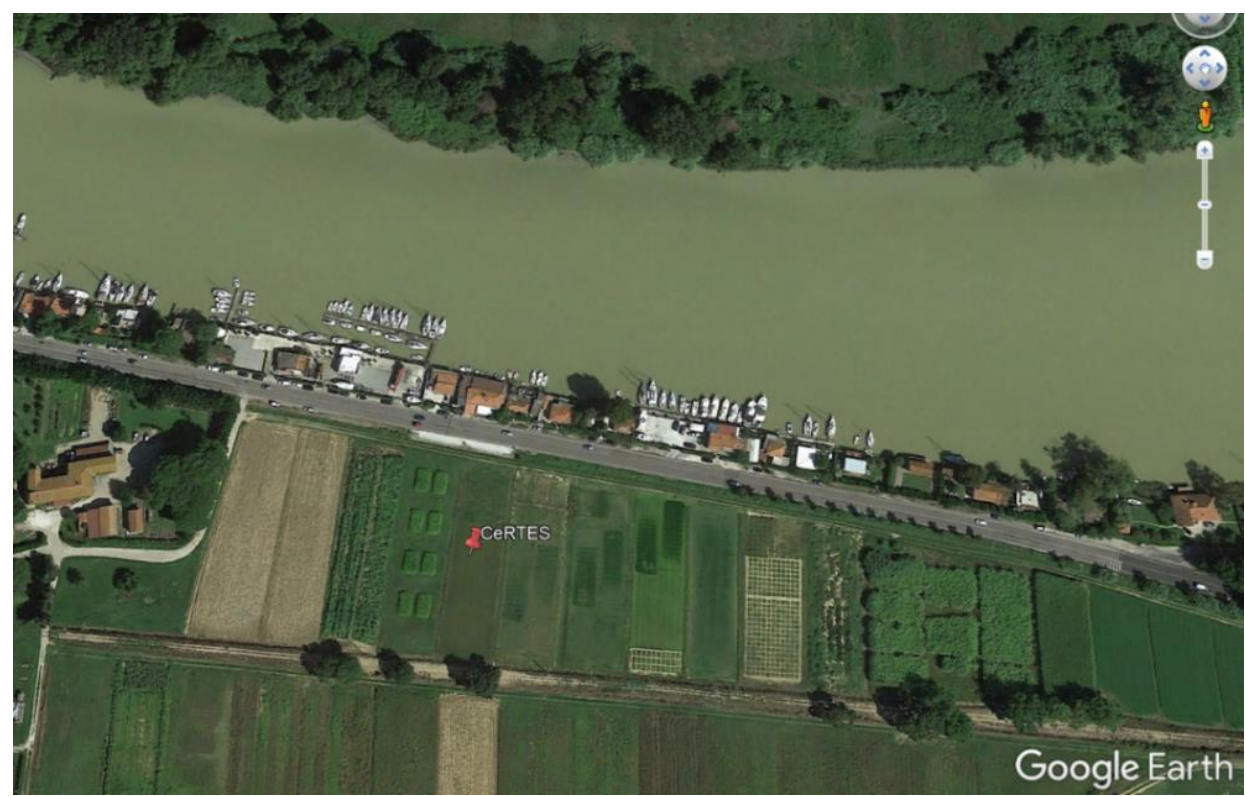

Figure 1. Satellite image of experimental area (CeRTES) and the surronding habitats (Source: Google Earth)

The trial was established on a calcaric fluvisol. The analyses of the main physical and chemical properties of soil (Table 1) were performed according to the Italian Ministry of Agriculture and Forestry procedures (MiPAF, 1994).

Table 1. Physical and chemical properties of the soil

\begin{tabular}{c|c|c}
\hline Properties & Measure unit & Value \\
\hline Sand & $\%$ & 28 \\
Silt & $\%$ & 55 \\
Clay & $\%$ & 17 \\
Organic matter & $\mathrm{g} \mathrm{kg}^{-1}$ & 21 \\
Total nitrogen & $\mathrm{g} \mathrm{kg}^{-1} \mathrm{~d} . \mathrm{m}$. & 1 \\
Available phosphorus & $\mathrm{mg} \mathrm{kg}^{-1}$ & 12 \\
Exchangeable potassium & $\mathrm{mg} \mathrm{kg}^{-1}$ & 126 \\
pH & & 7.7 \\
Cation Exchange Capacity & ${\mathrm{meq} 100 \mathrm{~g}^{-1}}^{-1}$ & 9.8 \\
Electric conductivity & $\mathrm{mS} \mathrm{cm}^{-1}$ & 0.2 \\
\hline
\end{tabular}

Eighteen plots of $1 \mathrm{~m} \times 1 \mathrm{~m}$ were organized with three fertilization treatments and three replicates per each species. Fertilization treatments were carried out once, at the beginning of the trial (7th May 2018) with a rotary spreader (ICL Specialty Fertilizers 
AccuPro 2000, Ipswich, UK), applying ammonium sulfate at three different levels as $0 \mathrm{~kg} \mathrm{~N} \mathrm{ha}^{-1}$ (Control), $50 \mathrm{~kg} \mathrm{~N} \mathrm{ha}^{-1}$ (N1, minimum conventional rate for both tall fescue and bermudagrass) (Carey et al., 2012), and $150 \mathrm{~kg} \mathrm{~N}^{-1}$ (N2, tripled minimum conventional rate). Weekly mowing at turf height of $2.0 \mathrm{~cm}$ was performed with a walkbehind lawnmower (John Deere 20SR7, Moline IL, USA) equipped with rear clippings bagger. In order to prevent drought stress, sprinkler irrigation was used when needed.

In this study, urban and peri-urban grasses were intended as a playing and ornamental surface for sport, relaxation and enjoyment and not as a pasture crops. For this reason, according to Kaye et al. (2004), Townsend-Small and Czimczik (2010), Kong et al. (2014), Van Delden et al. (2016), and Shchepeleva et al. (2017), carbon emissions were evaluated only through the quantification of fluxes without evaluating the dry matter production or the amount of carbon bound in the production. Eighteen static chambers (one per plot, nine per specie) were constructed as described by Parkin and Venterea (2010) and Verdi et al. (2018) for the monitoring of gas emissions (Fig. 2). Chambers were composed by an anchor system and the lid of the chamber. Anchor system was made by a PVC cylinder ( $20 \mathrm{~cm}$ diameter and $15 \mathrm{~cm}$ height). The anchor was inserted into the soil for approximately $10 \mathrm{~cm}$ as support for the lid. The lid of the chamber was made by a PVC cylinder (20 cm diameter and $25 \mathrm{~cm}$ height) and a PVC stopper sealed with a silicon glue. To reduce solar radiation disturbance of internal temperature of the chamber, a reflective Mylar tape was placed on the external surface of chamber's lid. To allow gas samplings, a hole of $13.2 \mathrm{~mm}$ diameter, was drilled on the top of the lid. A butyl rubber septum (20 mm diameter) was used to close the hole and allow gas samplings. Hermetic connection between anchor and the lid was ensured using a strip of tire tube of $7 \mathrm{~cm}$ that was sealed on the bottom of the lid with silicon glue. During measurements, the exceeding part of the strip from the lid (approximately 50\% of the strip) was folded down on the anchor system.

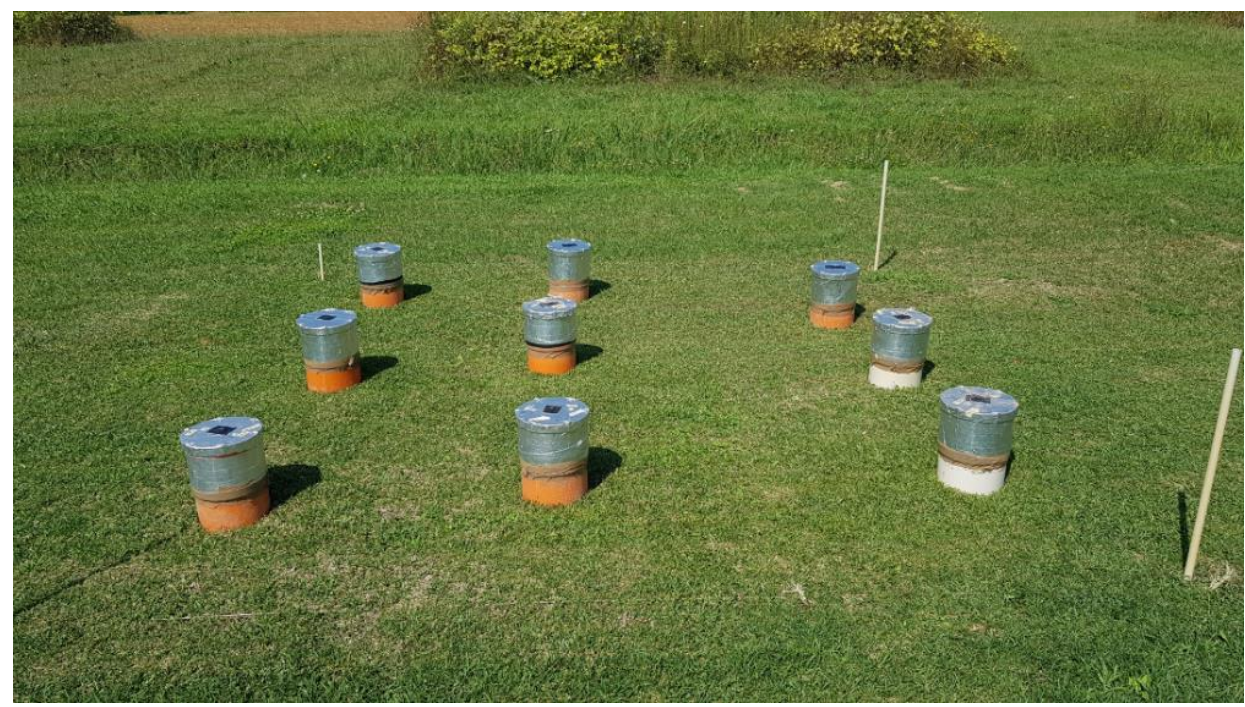

Figure 2. Static chambers for the monitoring of $\mathrm{CO}_{2}$ and $\mathrm{CH}_{4}$ emissions by turfgrass

Gas samplings were performed by means of a portable gas analyzer Madur Sensonic X-CGM 400 (Zgierz, PL). X-CGM 400 uses non-dispersive infrared (NDIR) technology for $\mathrm{CO}_{2}$ and $\mathrm{CH}_{4}$ monitoring. $\mathrm{X}-\mathrm{CGM} 400$ was connected by chambers with a pipe system 
equipped with a needle. Measurements were carried out by holding the needle inside the butyl rubber septum of the chamber for $1 \mathrm{~min}$. Air flow was pumped inside the X-CGM 400 and released outside the analyser at the end of the analysis. Gas concentration data were obtained directly from the analyser (ppm). Measurement consisted in two gas samplings per chamber: the first one immediately after chamber closing and the second one after $1 \mathrm{~h}$ intervals (Parkin and Venterea, 2010; Verdi et al., 2018) of gas accumulation into the closed chamber. Difference between the two samplings represents gas concentration into the chamber. Gas fluxes calculation was performed using gas concentration, air temperature, chamber dimensions (area, $314 \mathrm{~cm}^{2}$, and volume, $9420 \mathrm{~cm}^{3}$ ) and the molar weight of each gas to convert data from ppm to $\mathrm{Kg}-\mathrm{C} \mathrm{ha}{ }^{-1}$. Measurements were performed on mid-morning, from 9 am to $11 \mathrm{am}$, as it represents the time of the day that more closely corresponds to daily average temperature (Parkin and Venterea, 2010). $\mathrm{CO}_{2}$ and $\mathrm{CH}_{4}$ emissions monitoring were carried out on a period of 37 weeks from the day of the year (DOY) 127 (7th of May) to DOY 270 (17th September) in order to evaluate their trend and the total amount of $\mathrm{C}$ emissions. Measurements were carried out at 1, 3 and 5 days immediately after fertilization (DOY 127, 129 and 131, respectively), and once a week during the second and the third weeks. From the fourth week, measurements were performed once every two weeks, until the end of the experiment. Interpolation methodology was adopted to obtain missing data from the days when measurements were not performed.

Daily data of temperature (minimum, maximum and average) and precipitation were collected by a weather station of the Regional Hydrological Service of Tuscany located next to field trial in S. Piero a Grado (PI, Italy) (Fig. 3).

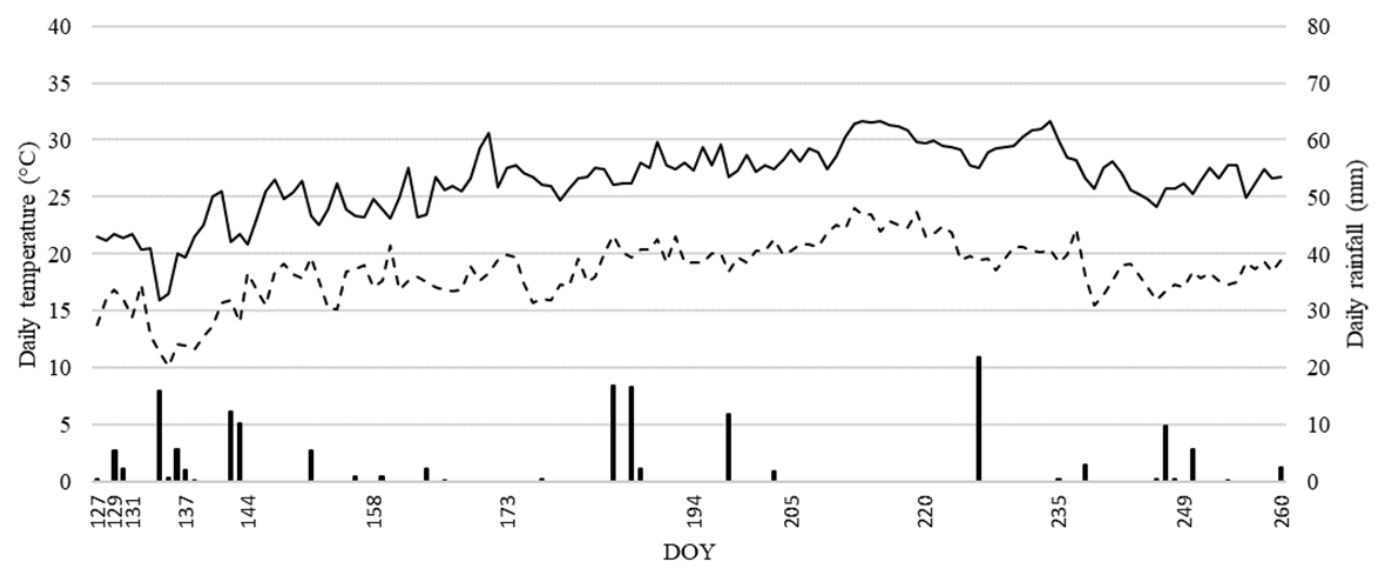

Figure 3. Maximum and minimum air temperatures trend and rainfall during monitoring period (DOY 127-DOY 260, 2018). Bars: precipitation (mm); solid line: maximum air temperature $\left({ }^{\circ} \mathrm{C}\right)$; dashed line: minimum air temperature $\left({ }^{\circ} \mathrm{C}\right)$. Numbers of DOY are in correspondence to GHG measurements

Statistical analysis was carried out according to CoStat software (Co Hort, Monterey, CA, USA). Carbon emission data of tall fescue and hybrid bermudagrass at the different $\mathrm{N}$ fertilization rates were analyzed using analysis of variance (ANOVA) followed by the Tukey's test to compare means at $p \leq 0.05$ level of significance. The relationships among $\mathrm{C}$ emission and $\mathrm{N}$ fertilization rates for the species were studied using Pearson's correlation coefficient (r). 


\section{Results and discussion}

\section{Carbon dioxide emissions}

In tall fescue $\mathrm{CO}_{2}$ emission flux didn't seem to be affected by the addition of $\mathrm{N} 1$, the conventional rate used in urban turfgrasses. In fact, no significant differences in total amount of $\mathrm{C}$ emissions between Control and N1 were observed (Table 2). Probably tall fescue uses organic matter in the soil more efficiently for its own development offsetting the lack of $\mathrm{N}$ in Control compared to $\mathrm{N} 1$. On the contrary significantly higher $\mathrm{CO}_{2}$ emissions were recorded under N2 rate. This is in accordance with Hamido et al. (2016) which state that an intense increase of $\mathrm{N}$ rate can cause greater soil $\mathrm{CO}_{2}$ emissions. A strong correlation $(\mathrm{r}=0.90)$ between soil $\mathrm{CO}_{2}$ emissions and $\mathrm{N}$ fertilization rates was observed (Table 3).

Table 2. Total amount of $\mathrm{C}$ emission $\left(\mathrm{kg} \mathrm{Cha}{ }^{-1}\right)$ in terms of carbon dioxide $\left(\mathrm{CO}_{2}\right)$ and methane $\left(\mathrm{CH}_{4}\right)$ at the end of the monitoring period (DOY 260) for tall fescue and hybrid bermudagrass at 0 (control), 50 (N1), 150 (N2) $\mathrm{kg} \mathrm{ha}^{-1}$ of N

\begin{tabular}{|c|c|c|c|c|}
\hline & $\begin{array}{c}\text { Tall fescue } \\
\mathrm{kg} \mathrm{CO}_{2}-\mathrm{C} \mathrm{ha}^{-1}\end{array}$ & $\begin{array}{l}\text { Bermudagrass } \\
\mathrm{kg} \mathrm{CO}_{2}-\mathrm{C} \mathrm{ha}^{-1}\end{array}$ & $\begin{array}{c}\text { Tall fescue } \\
\mathrm{kg} \mathrm{CH}_{4}-\mathrm{C} \mathrm{ha}{ }^{-1}\end{array}$ & $\begin{array}{l}\text { Bermudagrass } \\
\mathrm{kg} \mathrm{CH}_{4}-\mathrm{C} \mathrm{ha}\end{array}$ \\
\hline 0 (Control) & $4472 \mathrm{~b}^{\mathrm{a}}( \pm 1080)^{\mathrm{b}}$ & $5245 \mathrm{~b}( \pm 596)$ & $18.64 \mathrm{a}( \pm 2.84)$ & $15.69 \mathrm{a}( \pm 3.53)$ \\
\hline N1 & $5223 \mathrm{~b}( \pm 806)$ & 7137 a $( \pm 649)$ & $18.55 \mathrm{a}( \pm 1.33)$ & $21.24 \mathrm{a}( \pm 5.44)$ \\
\hline $\mathrm{N} 2$ & 7901 a $( \pm 599)$ & 7576 a $( \pm 1149)$ & $18.95 \mathrm{a}( \pm 1.95)$ & 14.32 a $( \pm 1.56)$ \\
\hline
\end{tabular}

a Values on the same column followed by different letters are significantly different at $\mathrm{p} \leq 0.05$,

b Standard deviation

Table 3. Relationships among $C$ emission and $N$ fertilization rates for tall fescue and bermudagrass

\begin{tabular}{c|c|c}
\hline & Tall fescue & Bermudagrass \\
\hline \multirow{2}{*}{$\mathrm{Kg} \mathrm{CO}_{2}-\mathrm{C}$} & $\mathrm{y}^{\mathrm{a}=23.421 \mathrm{x}+4304.6}$ & $\mathrm{y}=13.994 \mathrm{x}+5723.4$ \\
& $\mathrm{r}^{\mathrm{b}}=0.90^{* *}$ & $\mathrm{r}=0.71^{*}$ \\
$\mathrm{Kg} \mathrm{CH}_{4}-\mathrm{C}$ & $\mathrm{y}=-0.0042 \mathrm{x}+18.995$ & $\mathrm{y}=0.0033 \mathrm{x}+17.301$ \\
& $\mathrm{r}=0.15$ n.s. & $\mathrm{r}=0.047 \mathrm{n} . \mathrm{s}$. \\
\hline
\end{tabular}

a Regression equation,

b Pearson's correlation coefficient

In the short term, $\mathrm{CO}_{2}$ emissions of tall fescue were stimulated by fertilization (Fig. 4). $\mathrm{N} 2$ had an immediate effect on C emission, N1 about two days later (DOY 129). However, it seems to be evident that soil bacteria need some days for fertilizers degradation since the respiration peak $\left(75 \mathrm{~kg} \mathrm{CO}_{2}-\mathrm{C} \mathrm{ha}^{-1}\right.$ for $\mathrm{N} 2$ and $54 \mathrm{~kg} \mathrm{CO}_{2}-\mathrm{C} \mathrm{ha}^{-1}$ for N1) occurred 10 days after fertilization (DOY 137) (Fig. 4). Thereafter, as observed by Alluvione et al. (2010) in their experiments, all treatments showed a reduction in $\mathrm{CO}_{2}$ emissions. In particular, starting from 31 days (DOY 158) after fertilization until the end of the experiment, Control and $\mathrm{N} 1$ exhibited the same $\mathrm{CO}_{2}$ emissions trend. Conversely, $\mathrm{N} 2$ maintained significantly higher $\mathrm{CO}_{2}$ emissions than the other treatments until DOY 205 (Fig. 4). The average daily trends confirmed this result, showing significantly higher emissions in $\mathrm{N} 2\left(59.41 \mathrm{~kg} \mathrm{CO}_{2}-\mathrm{C} \mathrm{ha}^{-1} \mathrm{~d}^{1}\right)$ than in $\mathrm{N} 1$ and Control treatments (39.28 and $33.63 \mathrm{~kg} \mathrm{CO}_{2}-\mathrm{C} \mathrm{ha}{ }^{-1} \mathrm{~d}^{1}$, respectively). 

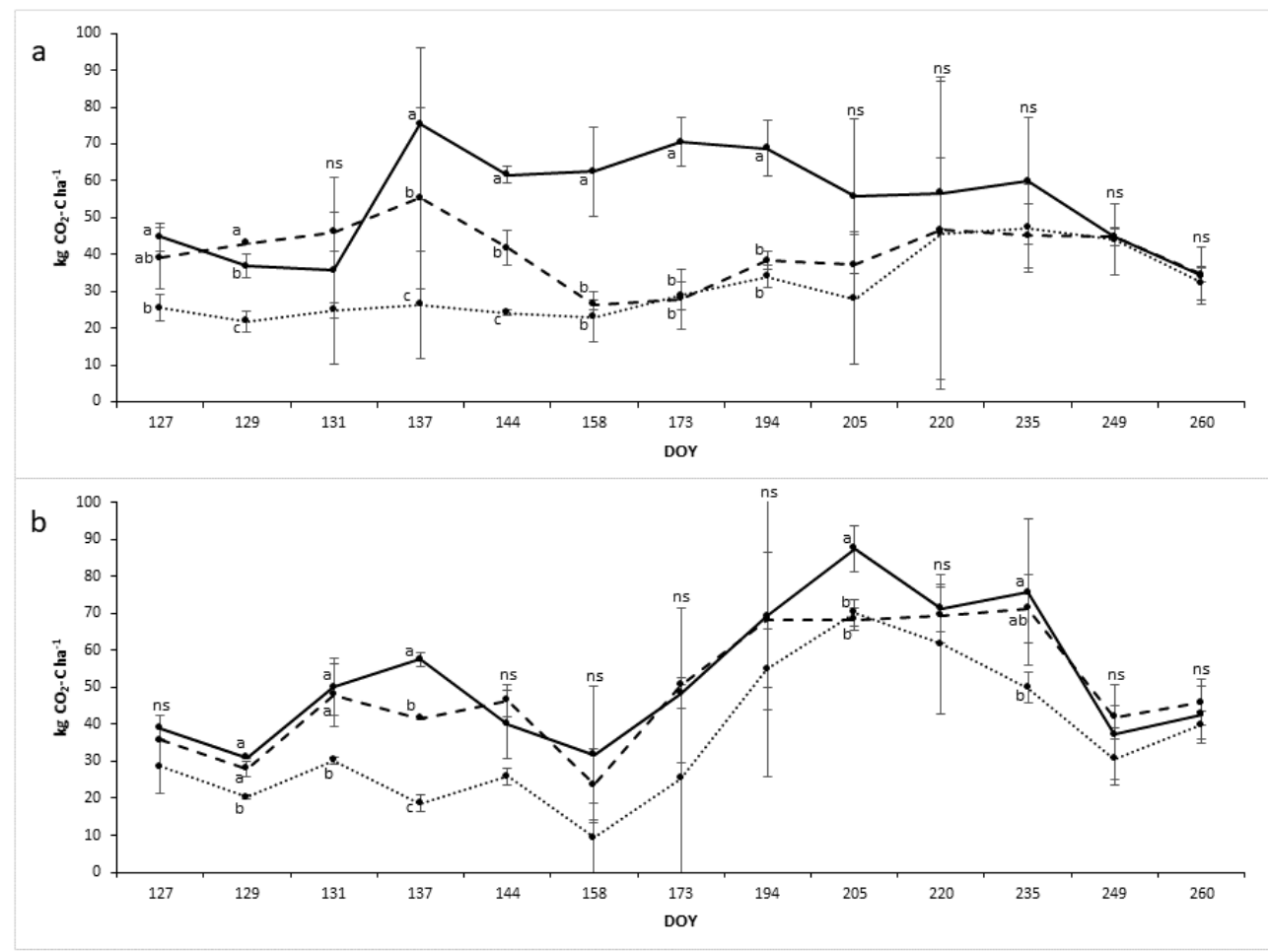

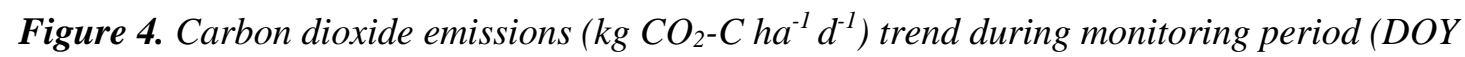
127 to DOY 260, 2018) from tall fescue (a) and hybrid bermudagrass (b) at 0 (control), 50 (N1), 150 (N2) kg ha-1 of N. Dotted line: control; dashed line: N1; solid line: N2. Vertical bars indicate standard deviation. Values with the same letter are not different according to Tukey test $(P \leq 0.05)$. Numbers of DOY are in correspondence to GHG measurements

Contrary to what observed in tall fescue, hybrid bermudagrass showed to be more reactive to $\mathrm{N}$ fertilization. In fact, soil microbial community and roots respiration was stimulated also at a low $\mathrm{N}$ input (Table 2). No significant differences on cumulative amounts of $\mathrm{CO}_{2}$ emissions between $\mathrm{N} 1$ and $\mathrm{N} 2$ were observed. However, both $\mathrm{N} 1$ and $\mathrm{N} 2$ showed higher values compared to Control (Table 2). This is in accordance to the average daily emission trends that showed similar values between $\mathrm{N} 1$ and $\mathrm{N} 2$ (53.66 and $56.96 \mathrm{~kg} \mathrm{CO}_{2}-\mathrm{C} \mathrm{ha}^{-1} \mathrm{~d}^{1}$, respectively) but significantly higher in respect with the Control treatment (39.44 $\left.\mathrm{kg} \mathrm{CO}_{2}-\mathrm{C} \mathrm{ha}^{-1} \mathrm{~d}^{1}\right)$. A weak correlation between soil $\mathrm{CO}_{2}$ emissions and $\mathrm{N}$ fertilization rates was observed $(\mathrm{r}=0.71)$ (Table 3). Immediately after fertilization, hybrid bermudagrass showed a reduction on soil $\mathrm{CO}_{2}$ emissions for all treatments. Fertilization affected C emissions starting from DOY 129 until DOY 137; N1 and Control showed the same trend with significant differences, N2 gradually increased until DOY 137 with significant differences with respect to $\mathrm{N} 1$ only at DOY 137 . This is in accordance with Alluvione et al. (2010) that observed a similar trend in $\mathrm{CO}_{2}$ emissions from corn, also belonging to Poaceae family. From DOY 144, C emissions trend seems to be influenced more by temperatures than by fertilization (Fig. 3). In fact, significant differences between treatments were observed only in few cases (DOY 205 and 235).

Our results show that turfs represent and effective strategy to reduce soil $\mathrm{CO}_{2}$ emissions fluxes when compared with other types of urban and peri-urban land use. As a matter of fact, we found a soil $\mathrm{CO}_{2}$ average emissions accounts to $47.1 \mathrm{~kg} \mathrm{CO}_{2}-\mathrm{C} \mathrm{ha}^{-1} \mathrm{~d}^{-1}$ (considering both the species and the $\mathrm{N}$ rates used in our experiment) while research on 
urban gardens reported daily $\mathrm{CO}_{2}$ emissions of $68.8 \mathrm{~kg} \mathrm{CO}_{2}-\mathrm{C}$ ha ${ }^{-1}$ (Predotova et al., 2010), $73.97 \mathrm{~kg} \mathrm{CO}_{2}-\mathrm{C} \mathrm{ha}^{-1}$ (Kaye et al., 2005), and $79.7 \mathrm{~kg} \mathrm{CO}_{2}-\mathrm{C}^{-1}$ (Lompo et al., 2012).

\section{Methane emissions}

In this experiment, $\mathrm{CH}_{4}$ emissions were not affected by $\mathrm{N}$ fertilization rate for both tall fescue and hybrid bermudagrass, as confirmed by the Person's correlation coefficients analysis reported in Table $3(\mathrm{r}=0.15$ and $\mathrm{r}=0.047$ for tall fescue and hybrid bermudagrass, respectively). This result is in accordance to Whalen (2005) and Oertel et al. (2016) who state that $\mathrm{CH}_{4}$ is mainly produced in anaerobic conditions typical of wetlands. Due to the ornamental function of turfs, turf's soils are generally characterized by a high draining potential to avoid waterlogging, hindering anaerobic conditions and $\mathrm{CH}_{4}$ emissions. In addition, the application of ammonium sulfate hampers $\mathrm{CH}_{4}$ emission by inhibiting the methanogenesis in paddy lands (Schütz et al., 1989; Cai et al., 1997; Le Mer and Roger, 2001).

No significant differences in $\mathrm{CH}_{4}$ emissions between treatments were observed in tall fescue (Table 2) confirming that dry climatic conditions (Fig. 3) as well as well-drained soil, hamper $\mathrm{CH}_{4}$ emissions. $\mathrm{CH}_{4}$ emissions showed an inconstant trend during the whole monitoring period. Differences were observed only at DOY 131 between Control and N2, and at DOY 144 when N2 resulted higher than the other treatments (Fig. 5).

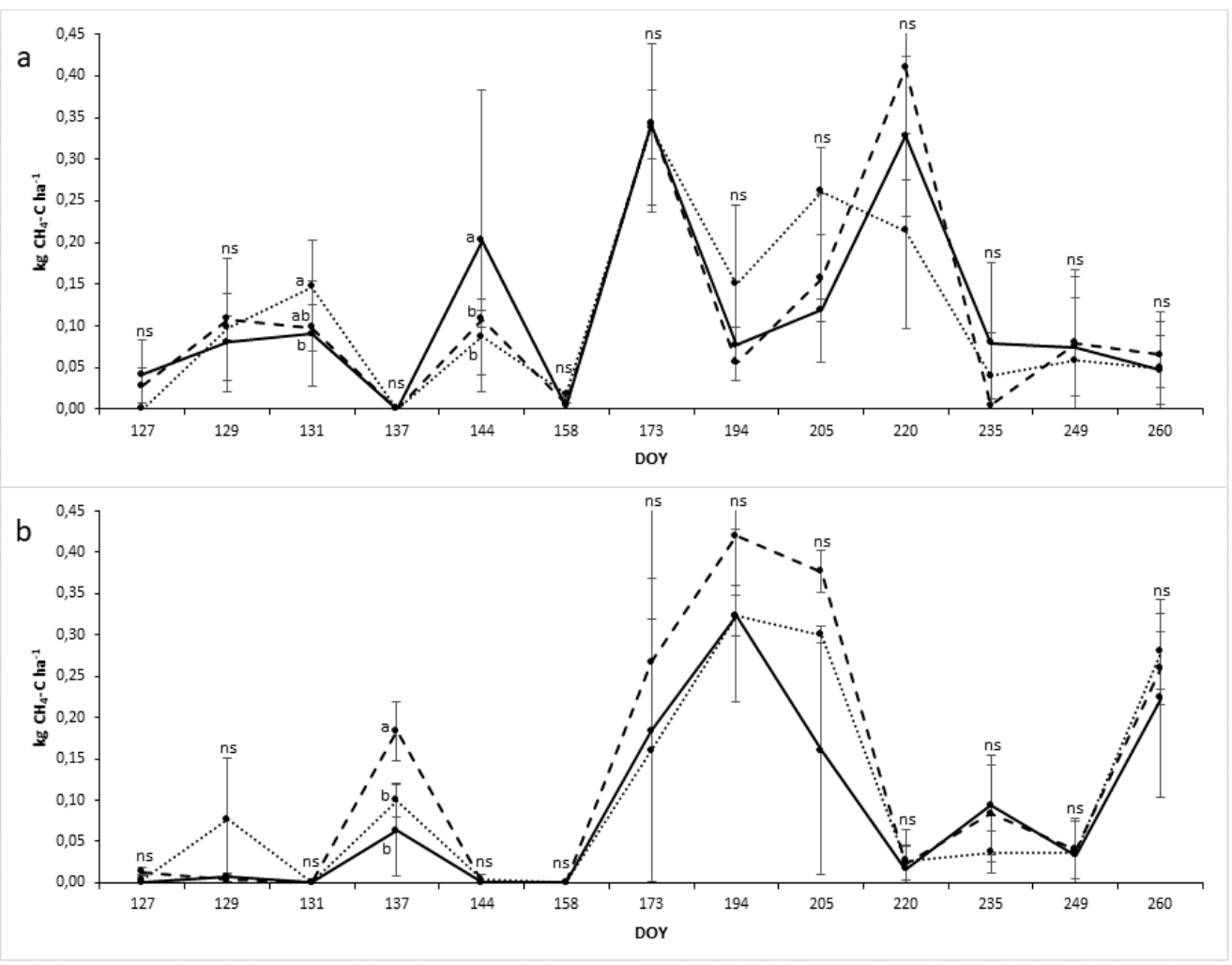

Figure 5. Methane emissions ( $\mathrm{g} \mathrm{CH}_{4} \mathrm{Ch} \mathrm{hal}^{-1} \mathrm{~d}^{-1}$ ) during monitoring period (DOY 127 to DOY 260, 2018) from tall fescue (a) and hybrid bermudagrass (b) at 0 (control), 50 (N1), 150 (N2) $\mathrm{kg} \mathrm{ha} a^{-1}$ of N. Dotted line: control; dashed line: N1; solid line: N2. Vertical bars indicate standard deviation. Values with the same letter are not different according to Tukey test $(P \leq 0.05)$. Numbers of DOY are in correspondence to GHG measurements 
As observed in tall fescue, no significant results were obtained relatively to the effect of $\mathrm{N}$ fertilization rate on cumulative $\mathrm{CH}_{4}$ emission fluxes of hybrid bermudagrass (Table 2). This is supported by the inconstancy in $\mathrm{CH}_{4}$ emission fluxes during the monitoring period (Fig. 5). The main $\mathrm{CH}_{4}$ production occurred between DOY 158 and DOY 220 in correspondence of the highest vegetative activity of the turf. Moreover, $\mathrm{CH}_{4}$ emissions peaks mainly occurred some days after a period of cumulative precipitations of at least $10 \mathrm{~mm}$ of rain. In particular, at DOY 137, 194 and 235 the main $\mathrm{CH}_{4}$ production were observed. If on one hand this is in accordance to Le Mer and Roger (2001) that observed a high correlation between soil water content and $\mathrm{CH}_{4}$ emissions, from on the other hand tall fescue did not show the same results. This is probably due to the tendency of a mature hybrid bermudagrass stand to create a layer of partially decomposed plant material (thatch) at soil surface thus reducing soil aeration and $\mathrm{CH}_{4}$ oxidation (Mc Carty and Miller, 2002).

To our knowledge, only few studies on $\mathrm{CH}_{4}$ emissions by urban turfgrasses, measured with static-chambers, have been conducted yet (Kaye et al., 2004; Groffman and Pouyat, 2009), and no information is available on other type of urban vegetation. Nevertheless, on the contrary to what observed by Kaye et al. (2004) and Groffman and Pouyat (2009), which affirmed that urban lawns are a small net-sink for $\mathrm{CH}_{4}$, our results indicate that turf could be considered a small source $\left(0.049 \mathrm{~kg} \mathrm{CH}_{4} \mathrm{C} \mathrm{ha}^{-1} \mathrm{~d}^{-1}\right)$.

\section{Conclusions}

The massive presence of turfgrasses in urban areas makes it necessary to study the environmental impact of their design and management. Fertilization leads to $\mathrm{CO}_{2}$ emissions from turfgrasses. In this study, nitrogen fertilization induced a low response in tall fescue with similar $\mathrm{CO}_{2}$ emissions production between zero and low fertilization rates. On the contrary, hybrid bermudagrass was more sensitive to nitrogen fertilization and $\mathrm{CO}_{2}$ emissions were stimulated both at low and high $\mathrm{N}$ fertilization rates. Nevertheless, similar production of $\mathrm{CO}_{2}$ was observed between species at the same $\mathrm{N}$ rate. No substantial impacts were observed in $\mathrm{CH}_{4}$ emissions.

Hence, our results highlight that $\mathrm{N}$ fertilization management and turf species affect $\mathrm{CO}_{2}$ emissions. An accurate management of these two features may represent a key factor on $\mathrm{C}$ dynamics in green areas.

The authors suggest that further experiments should be focused on the estimation of the role of different turfgrass management practices and species on $\mathrm{C}$ storage capacity and GHG emissions. It might be interesting to evaluate the impact of $\mathrm{N}$ fertilizers type and time of application as well as the irrigation effect together with clipping management.

Accordingly, this study contributes to broadening the knowledge on a topic of international interest such as climate change and adds information about the management of two of the most used grass species in Mediterranean environment.

For this reason, the assessment of direct soil carbon emissions from different turf species may be considered exhaustive for the evaluation of urban environment.

\section{REFERENCES}

[1] Alig, R. J., Kline, J. D., Lichtenstein, M. (2004): Urbanization on the US landscape: looking ahead in the 21st century. - Landscape and Urban Planning 69(2-3): 219-234. 
[2] Allaire, S. E., Dufour-L'Arrivée, C., Lafond, J. A., Lalancette, R., Brodeur, J. (2008): Carbon dioxide emissions by urban turfgrass areas. - Canadian Journal of Soil Science 88(4): 529-532.

[3] Alluvione, F., Bertora, C., Zavattaro, L., Grignani, C. (2010): Nitrous oxide and carbon dioxide emissions following green manure and compost fertilization in corn. - Soil Science Society of American Journal 74(2): 384-395.

[4] Cai, Z., Xing, G., Yan, X., Xu, H., Tsuruta, H., Yagi, K., Minami, K. (1997): Methane and nitrous oxide emissions from rice paddy fields as affected by nitrogen fertilisers and water management. - Plant and Soil 196(1): 7-14.

[5] Carey, R. O., Hochmuth, G. J., Martinez, C. J., Boyer, T. H., Nair, V. D., Dukes, M. D., Toor, G. S., Shober, A. L., Cisar, J. L., Threnholm, L. E., Sartain, J. B. (2012): A review of turfgrass fertilizer management practices: Implications for urban water quality. HortTechnology 22(3): 280-291.

[6] Caturegli, L., Lulli, F., Foschi, L., Guglielminetti, L., Bonari, E., Volterrani, M. (2014): Monitoring turfgrass species and cultivars by spectral reflectance. - European Journal of Horticultural Science 79(3): 97-107.

[7] Caturegli, L., Lulli, F., Foschi, L., Guglielminetti, L., Bonari, E., Volterrani, M. (2015): Turfgrass spectral reflectance: simulating satellite monitoring of spectral signatures of main $\mathrm{C}_{3}$ and $\mathrm{C}_{4}$ species. - Precision Agriculture 16(3): 297-310.

[8] d'Amour, C. B., Reitsma, F., Baiocchi, G., Barthel, S., Güneralp, B., Erb, K. H., Haberl, H., Creutzig, F., Seto, K. C. (2017): Future urban land expansion and implications for global croplands. - Proceedings of the National Academy of Sciences 114(34): 8939-8944.

[9] Foley, J. A., Defries, R., Asner, G. P., Barford, C., Bonan, G., Carpenter, S. R., Chapin, F. S., Coe, M. T., Daily, G. C., Gibbs, H. K., Helkowsky, J. H., Holloway, T., Howard, E. A., Kucharik, C. J., Monfreda, C., Patz, J. A., Prentice, I. C., Ramankutty, N., Snyde, P. K. (2005): Global consequences of land use. - Science 309: 570-574.

[10] Forster, P., Ramaswamy, V., Artaxo, P., Berntsen, T., Betts, R., Fahey, D. W., Haywood, J., Lean, J., Lowe, D. C., Myhre, G., Nganga, J., Prinn, R., Raga, G., Schulz, M., Van Dorland, R. (2007): Changes in atmospheric constituents and in radiative forcing. Chapter 2. - In: Solomon, S., Qin, D., Manning, M., Chen, Z., Marquis, M., Averyt, K. B., Tignor, M., Miller, H. L. (eds.) Climate Change 2007. The Physical Science Basis. Contribution of Working Group I to the Fourth Assessment Report of the Intergovernmental Panel on Climate Change. Cambridge University Press, Cambridge, United Kingdom and New York, NY, USA, pp. 129-234.

[11] Groffman, P. M., Pouyat, R. V. (2009): Methane uptake in urban forests and lawns. Environmental Science \& Technology 43(14): 5229-5235.

[12] Hamido, S. A., Wood, C. W., Guertal, E. A. (2016): Carbon dioxide flux from bermudagrass turf as affected by nitrogen rate. - Agronomy Journal 108(3): 1000-1006.

[13] Houghton, R. A., Hackler, J. L., Cushman, R. M. (2001): Carbon flux to the atmosphere from land-use changes: 1850 to 1990. - Oak Ridge: Carbon Dioxide Information Center, Environmental Sciences Division, Oak Ridge National Laboratory.

[14] Ignatieva, M., Ahrné, K., Wissman, J., Eriksson, T., Tidåker, P., Hedblom, M., Katterer, T., Marstorp, H., Berg, P., Eriksson, T., Bengtsson, J. (2015): Lawn as a cultural and ecological phenomenon: a conceptual framework for transdisciplinary research. - Urban Forestru \& Urban Greening 14(2): 383-387.

[15] Jo, H. K., McPherson, G. E. (1995): Carbon storage and flux in urban residential greenspace. - Journal of Environmental Management 45(2): 109-133.

[16] Jo, H. K. (2002): Impacts of urban greenspace on offsetting carbon emissions for middle Korea. - Journal of Environmental Management 64(2): 115-126.

[17] Kaye, J. P., Burke, I. C., Mosier, A. R., Guerscham, J. (2004): Methane and nitrous oxide fluxes from urban soils to the atmosphere. - Ecological Applied 14(4): 975-981. 
[18] Kaye, J. P., McCulley, R. L., Burke, I. C. (2005): Carbon fluxes, nitrogen cycling, and soil microbial communities in adjacent urban, native and agricultural ecosystems. - Global Change Biology 11(4): 575-587.

[19] Kong, L., Shi, Z., Chu, L. M. (2014): Carbon emission and sequestration of urban turfgrass systems in Hong Kong. - Science of the Total Environment 473: 132-138.

[20] Lal, R., Kimble, J., Stewart, B. A. (1995): World soils as a source or sink for radiativelyactive gases. - In: Lal, R., Kimble, J., Levine, E. R., Stewart, B. A. (eds.) Soil Management and Greenhouse Effect. Lewis Publishing Inc., Boca Raton, pp.1-8.

[21] Le Mer, J., Roger, P. (2001): Production, oxidation, emission and consumption of methane by soils: a review. - European Journal of Soil Biology 37(1): 25-50.

[22] Lompo, D. J. P., Sangaré, S. A. K., Compaoré, E., Papoada Sedogo, M., Predotova, M., Schlecht, E., Buerkert, A. (2012): Gaseous emissions of nitrogen and carbon from urban vegetable gardens in Bobo-Dioulasso, Burkina Faso. - Journal of Plant Nutrition and Soil Science 175(6): 846-853.

[23] Ludwig, J., Meixner, F. X., Vogel, B., Förstner, J. (2001): Soil-air exchange of nitric oxide: an overview of processes, environmental factors, and modeling studies. - Biogeochemistry 52: 225-257.

[24] Magni, S., Gaetani, M., Grossi, N., Caturegli, L., La Bella, S., Leto, C., Virga, G., Tuttolomondo, T., Lulli, F., Volterrani, M. (2014): Bermudagrass adaptation in the Mediterranean climate: phenotypic traits of 44 accessions. - Advances in Horticultural Science 28(1): 29-34.

[25] Mc Carty, L. B., Miller, G. (2002): Managing Bermudagrass turf. Seelection, construction, cultural practices, and pest management strategies. - John Wiley \& Sons., Ann. Arbor. Press., Chelsea (MI).

[26] Milesi, C., Running, S. W., Elvidge, C. D., Dietz, J. B., Tuttle, B. T., Nemani, R. R. (2005): Mapping and modeling the biogeochemical cycling of turf grasses in the United States. Environmental Management 36(3): 426-438.

[27] MiPAF (1994): Metodi ufficiali di analisi chimica e fisica del suolo. - MiPAF, Rome, Italy.

[28] Nowak, D. J., Crane, D. E. (2002): Carbon storage and sequestration by urban trees in the USA. - Environmental Pollution 116(3): 381-389.

[29] Oertel, C., Matschullat, J., Zurba, K., Zimmermann, F., Erasmi, S. (2016): Greenhouse gas emissions from soils - A review. - Geochemistry 76: 327-352.

[30] Parkin, T. B., Venterea, R. T. (2010): USDA-ARS GRACEnet Project Protocols, Chapter 3. - In: Follett, R. F. (ed.) Chamber-based Trace Gas Flux Measurements. Sampling Protocols. Beltsville, MD, pp. 1-39.

[31] Patra, S., Sahoo, S., Mishra, P., Chandra, S. C. (2018): Impacts of urbanization on land use/cover changes and its probable implications on local climate and groundwater level. Journal of Urban Management 7(2): 70-84.

[32] Pouyat, R., Groffman, P., Yesilonis, I., Hernandez, L. (2002): Soil carbon pools and fluxes in urban ecosystems. - Environmental Pollution 116: S107-S118.

[33] Pouyat, R. V., Yesilonis, I. D., Nowak, D. J. (2006): Carbon storage by urban soils in the United States. - Journal of Environmental Quality 35(4): 1566-1575.

[34] Predotova, M., Gebauer, J., Diogo, R. V., Schlecht, E., Buerkert, A. (2010): Emissions of ammonia, nitrous oxide and carbon dioxide from urban gardens in Niamey, Niger. - Field Crops Research 115(1): 1-8.

[35] Qian, Y., Follett, R. (2012): Carbon dynamics and sequestration in urban turfgrass ecosystems. - In: Lal, R., Augustin, B. (eds.) Carbon Sequestration in Urban Ecosystems. Springer, Dordrecht, pp. 161-172.

[36] Rastogi, M., Singh, S., Pathak, H. (2002): Emission of carbon dioxide from soil. - Current Science 82(5): 510-517.

[37] Ritchie, N., Roser, M. (2020): Urbanization. - Published online at OurWorldInData.org. Retrieved from: https://ourworldindata.org/urbanization. 
[38] Robbins, P., Birkenholtz, T. (2003): Turfgrass revolution: measuring the expansion of the American lawn. - Land Use Policy 20(2): 181-194.

[39] Schütz, H., Seiler, W., Conrad, R. (1989): Processes involved in formation and emission of methane in rice paddies. - Biogeochemistry 7(1): 33-53.

[40] Selhorst, A., Lal, R. (2013): Net carbon sequestration potential and emissions in home lawn turfgrasses of the United States. - Environmental Management 51(1): 198-208.

[41] Shchepeleva, A. S., Vasenev, V. I., Mazirov, I. M., Vasenev, I. I., Prokhorov, I. S., Gosse, D. D. (2017): Changes of soil organic carbon stocks and $\mathrm{CO}_{2}$ emissions at the early stages of urban turf grasses' development. - Urban Ecosystems 20(2): 309-321.

[42] Townsend-Small, A., Czimczik, C. I. (2010): Carbon sequestration and greenhouse gas emissions in urban turf. - Geophysical Research Letters 37(2): L02707.

[43] United Nations, Department of Economic and Social Affairs, Population Division (2014): World Urbanization Prospects: The 2014 Revision. - Highlights (ST/ESA/SER.A/352).

[44] van Delden, L., Larsen, E., Rowlings, D., Scheer, C., Grace, P. (2016): Establishing turf grass increases soil greenhouse gas emissions in peri-urban environments. - Urban Ecosystems 19(2): 749-762.

[45] Verdi, L., Mancini, M., Ljubojevic, M., Orlandini, S., Dalla Marta, A. (2018): Greenhouse gas and ammonia emissions from soil: The effect of organic matter and fertilisation method. - Italian Journal of Agronomy 13(3): 260-266.

[46] Verdi, L., Kuikman, P. J., Orlandini, S., Mancini, M., Napoli, M., Dalla Marta, A. (2019): Does the use of digestate to replace mineral fertilizers have less emissions of $\mathrm{N}_{2} \mathrm{O}$ and $\mathrm{NH}_{3}$ ? - Agricultural and Forestry Meteorology 269: 112-118.

[47] Whalen, S. C. (2005): Biogeochemistry of methane exchange between natural wetlands and the atmosphere. - Environmental Engineering Science 22: 73-94.

[48] Zhang, Y., Qian, Y., Bremer, D. J., Kaye, J. P. (2013): Simulation of nitrous oxide emissions and estimation of global warming potential in turfgrass systems using the DAYCENT Model. - Journal of Environmental Quality 42: 1100-1108. 